\title{
Self-regulation in collaborative environments : the case of the equator principles in banking
}

Citation for published version (APA):

Bos, J. W. B., Contreras, M. G., \& Kleimeier, S. (2016). Self-regulation in collaborative environments : the case of the equator principles in banking. Maastricht University, Graduate School of Business and Economics. GSBE Research Memoranda No. 007 https://doi.org/10.26481/umagsb.2016007

Document status and date:

Published: 01/01/2016

DOI:

10.26481/umagsb.2016007

Document Version:

Publisher's PDF, also known as Version of record

\section{Please check the document version of this publication:}

- A submitted manuscript is the version of the article upon submission and before peer-review. There can be important differences between the submitted version and the official published version of record.

People interested in the research are advised to contact the author for the final version of the publication, or visit the DOI to the publisher's website.

- The final author version and the galley proof are versions of the publication after peer review.

- The final published version features the final layout of the paper including the volume, issue and page numbers.

Link to publication

\footnotetext{
General rights rights.

- You may freely distribute the URL identifying the publication in the public portal. please follow below link for the End User Agreement:

www.umlib.nl/taverne-license

Take down policy

If you believe that this document breaches copyright please contact us at:

repository@maastrichtuniversity.nl

providing details and we will investigate your claim.
}

Copyright and moral rights for the publications made accessible in the public portal are retained by the authors and/or other copyright owners and it is a condition of accessing publications that users recognise and abide by the legal requirements associated with these

- Users may download and print one copy of any publication from the public portal for the purpose of private study or research.

- You may not further distribute the material or use it for any profit-making activity or commercial gain

If the publication is distributed under the terms of Article $25 \mathrm{fa}$ of the Dutch Copyright Act, indicated by the "Taverne" license above, 
Jaap W.B. Bos, Gaby Contreras, Stefanie Kleimeier

Self-Regulation in Collaborative Environments: The Case of the Equator Principles in Banking

$\mathrm{RM} / 16 / 007$

\section{GSBE}

Maastricht University School of Business and Economics

Graduate School of Business and Economics

P.O Box 616

NL-6200 MD Maastricht

The Netherlands 


\title{
Self-Regulation in Collaborative Environments: The Case of the Equator Principles in Banking*
}

\author{
Jaap W.B. Bos ${ }^{\dagger 1}$, Gaby Contreras ${ }^{\ddagger 2}$, and Stefanie Kleimeier ${ }^{\S 1,3,4}$ \\ ${ }^{1}$ Maastricht University, Tongersestraat 53, 6211 LM Maastricht, The Netherlands \\ ${ }^{2}$ Radboud University, Thomas van Aquinostraat 5, 6525 HP Nijmegen, The Netherlands \\ ${ }^{3}$ University of Stellenbosch Business School, Carl Cronje Dr., Cape Town 7530, South Africa \\ ${ }^{4}$ Open Universiteit, Valkenburgerweg 177, 6419 AT Heerlen, The Netherlands
}

\begin{abstract}
Using banks in the syndicated lending market, we discuss a firm-specific strategy that has been overlooked by the literature, namely, that self-regulated firms pressure other non-self-regulated firms in an attempt to reduce effort asymmetries when collaborating. We develop a framework that shows when such a strategy is likely to be present. This framework is built on the view that the costs and benefits of collaboration are equally shared among self-regulated firms that collaborate. However, when self-regulated firms collaborate with non-self-regulated firms, the effort they exert differs and is not equally shared. In particular, we find that when firms collaborate, self-regulated firms pressure non-self-regulated firms to become self-regulated with the purpose of reducing effort asymmetries, and such a pressure increases with the duration of the collaboration.
\end{abstract}

\section{Keywords:}

Peer effects, self-regulation, inter-organizational networks, syndicated lending, collaboration.

\footnotetext{
${ }^{*}$ We are grateful to all those who provided insightful comments to earlier versions of this paper, in particular Lammertjan Dam (University of Groningen), James Brown (University of Iowa) and Robin Cowan (Maastricht University, University of Strasbourg and UNU-Merit) who discussed this paper at the 2014 INFINITI Conference in Prato, Italy and at the 2014 Financial Management Association (FMA) European Conference in Maastricht, The Netherlands, respectively. In addition, we would like to thank all participants at the Maastricht UniversityHEC Liège-Luxembourg University-Aachen University Ph.D. Colloquium Day (Maastricht, The Netherlands), the 5th International Conference on Sustainability Transitions Conference (Utrecht, The Netherlands), the 2nd Geneva Summit on Sustainable Finance (Geneva, Switzerland), the 2014 UNamur-UCL Winter School and Workshop on Networks in Economics and Finance (Louvain-la-Neuve, Belgium), and Radboud University's School of Management Seminar Series (Nijmegen, The Netherlands). All direct correspondence to Martha Gabriela Contreras, Department of Economics \& Business Economics, Radboud University in Nijmegen, The Netherlands. E-mail: M.Contreras@fm.ru.nl
}

${ }^{\dagger} \bowtie$ J.Bos@maastrichtuniversity.nl, $\approx+314338848$ 44, +31 433884875 (Fax)

汹M.Contreras@fm.ru.nl, $\mathbf{\boldsymbol { 0 }}+31243613057,+31243612379$ (Fax)

§四S.Kleimeier@maastrichtuniversity.nl, $\mathbf{0}+314338837$ 33, +31 433884875 (Fax) 


\section{Introduction}

A firm's reaction to customer pressure and threats for stricter regulation is often to selfregulate (Segerson and Miceli, 1998; Maxwell, Lyon, and Hackett, 2000; Grajzl and Murrell, 2007; Pistor and Xu, 2003; Lenox and Nash, 2003). While firms are typically assumed to interact with customers and governmental agents when opting for self-regulation, firms also interact with other firms in the industry they belong to and such interactions may also influence self-regulation choices by firms. The existing literature overlooks these inter-firm interactions when studying self-regulation and our study fills this gap. In particular, we investigate the adoption of self-regulation by firms interacting through collaboration with the aim to advance our understanding of how inter-firm collaborations affect the degree and speed at which firms self-regulate.

We use the global syndicated lending market to discuss a firm-specific strategy overlooked by the literature, namely, that self-regulated firms pressure non-self-regulated firms in an attempt to reduce effort asymmetries when collaborating. We develop a framework to show when such a strategy is likely to be present. This framework is built on the view that the costs and benefits of collaboration are equally shared among self-regulated firms that collaborate. However, when self-regulated firms collaborate with non-self-regulated firms, the effort they exert is likely to differ. In particular, we find that when firms collaborate, self-regulated firms pressure non-self-regulated firms to become self-regulated with the purpose of reducing effort asymmetries, and such pressure increases with the length of their collaboration.

This paper is organized as follows. Section 2 presents the theory and hypothesis. Section 3 presents the empirical framework, and section 4 presents the data used. Section 5 contains the results, followed by robustness tests in section 6 . Section 7 concludes.

\section{Theory and hypothesis}

Self-regulation by firms is a fast growing and important complement to existing regulation and policies (Kolk and van Tulder, 2002; Grajzl and Murrell, 2007). Following the ramping up of market internationalization and globalization in the 1980s, international production and investment became more complex creating a momentum for new regulatory initiatives (Kolk and van Tulder, 2002). Since then, firms operating transnationally have been often 
challenged by governments and Non-Governmental Organizations (NGOs) to develop and adopt new forms of regulation to address their transnational practices. Consequently, by the early 2000s, a total of two thousand forms of self-regulation pertaining to issues ranging from maritime transport, taxation, lending, to human rights existed (Kolk and van Tulder, 2002).

Self-regulation is often a firm's strategic response to restrict its own conduct to avoid stiffer regulation by the government (Segerson and Miceli, 1998; Maxwell, Lyon, and Hackett, 2000; Grajzl and Murrell, 2007; Pistor and Xu, 2003; Lenox and Nash, 2003). As such, self-regulation has been studied as the interplay among three set of actors: consumers, firms and government (Maxwell, Lyon, and Hackett, 2000; Nunez, 2001; DeMarzo, Fishman, and Hagerty, 2005; Grajzl and Murrell, 2007). According to this setting, consumers purchasing products from firms pressure the government, some times through NGOs or other organizations, to implement a stricter regulation onto firms because a stricter regulation is expected to decrease any information asymmetries about the product and services firms supply (Grajzl and Murrell, 2007). In this way, consumers are able to discriminate the firms providing high-quality products and services from those that do not. As a result, governments respond to consumers' pressure by threatening firms with imposing mandatory regulation. Consequently, firms trade in the mandatory regulation for self-regulation (Grajzl and Murrell, 2007; Maxwell, Lyon, and Hackett, 2000). Such an interplay among customers, government and firms is illustrated in the right-hand side triangle in Figure 1.

[Insert Figure 1 here]

Self-regulation can strategically prevent governmental regulation often resulting in selfregulated firms experiencing a higher demand because the uncertainty about product and service quality decreases. Self-regulation tends to soften competition among participating firms, and typically improves a firm's reputation (Maxwell, Lyon, and Hackett, 2000; Short and Toffel, 2010; King, Lenox, and Terlaak, 2005; Potoski and Prakash, 2005; Benabou and Tirole, 2006; Arora and Cason, 1995). Firms may also choose to self-regulate in order to differentiate their products, reduce risk, reduce insurance premiums, circumvent government failure, improve their customer relationships, implement and/or increase standards along the supply chain, and/or avoid boycotts and formal accusations (Lenox and Nash, 2003; Diller, 1999; van Tulder and Kolk, 2001). Furthermore, the legal environment surrounding firms may also influence their choice for self-regulation. For example, 
Maxwell, Lyon, and Hackett (2000), Grajzl and Murrell (2007) and LaPorta, de Silanes, Schleifer, and Vishny (1997) find that self-regulation is also contingent on firms being located in a country with a civil law system. Granted, not every firm and industry opt for self-regulation. Possible reasons for not self-regulating include opportunity costs and lack of improved financial performance (Lenox and Nash, 2003; Maxwell, Lyon, and Hackett, 2000).

But what role does firm collaboration and interaction play in self-regulation? As governments respond to consumer pressure and urge firms to self-regulate, firms' best response may very well be a collective action (Lenox and Nash, 2003), e.g., firms jointly becoming self-regulated with the purpose of restricting their own conduct in order to avoid a mandatory regulation from the government. An important condition for collective action to occur is for firms to have some form of interaction, which may occur through collaboration among firms, as illustrated in the left-hand side section of Figure 1. To understand how firm interactions facilitate or hinder collective action, we need to understand who bears the costs and benefits of self-regulation. With perfect collective action, e.g., a situation where all firms in an industry become self-regulated, all firms bear the regulatory effort cost and reap the benefits. In contrast, when only some firms in the industry self-regulate, selfregulation can lead to an effort asymmetry between self- and non-self-regulated firms. To see why this is the case, let us start from the premise that the self-regulated firm is committed to being self-regulated and to deliver the high-quality product the consumer expects. Therefore, the self-regulated firm faces a choice between two possible actions. On the one hand, the self-regulated firm may choose to collaborate with the non-self-regulated firm as it results in the latter ripping collaboration benefits without exerting the effort the selfregulated firm is required to exert in order to produce the high-quality product consumers expect. On the other hand, because of the difference in effort exerted, the self-regulated firm may opt to pressure the non-self-regulated firm into becoming self-regulated as well. By peer pressuring the firm with whom it collaborates, the self-regulated firm aims at reducing future effort and increasing the number of self-regulated firms. As more firms become self-regulated, the reputation and credibility of the self-regulation increases, and it legitimizes (Potoski and Prakash, 2005). Our main hypothesis is thus:

Hypothesis: Self-regulated firms pressure their peers to adopt self-regulation. 


\section{The case of the Equator Principles}

An example of the theory described in the previous section is observed among collaborative banks that may self-regulate by adopting the Equator Principles, an industry-wide set of voluntary guidelines for promoting social and environmental responsibility among banks. Before explaining the role peer pressure plays in bank self-regulation, we first explain the Equator Principles and their role in bank lending.

Before 2003, an industry-wide legislation addressing the environmental and social risks associated with bank lending was non-existent (Esty and Sesia, 2005; Scholtens and Dam, 2007). Consequently, banks were targets of high-profile campaigns from NGO's and other organizations for their involvement in projects with large and negative environmental and social damages. This lack of an industry-wide regulation in combination with these campaigns pressured the banking sector into developing a form of regulation to address such issues. As a result a set of voluntary guidelines, or self-regulation, called the Equator Principles were drafted to promote social and environmental responsibility among banks. On June 4, 2003 eight banks announced the voluntary adoption of these principles (Scholtens and Dam, 2007; Esty and Sesia, 2005). The eight banks first adopting the Equator Principles were Barclays (United Kingdom), Citigroup (United States), Crèdit Swisse Group (Switzerland), Crèdit Agricole (France), Rabobank (the Netherlands), Royal Bank of Scotland (Scotland), UniCredit Bank (Germany), and Westpac Banking Corporation (Australia). By the end of 2010, a total of 50 banks from 35 different countries worldwide had adopted the Equator Principles. ${ }^{1}$

The Equator Principles apply to a specific type of bank lending called project finance, which is a form of long-term financing primarily used for infrastructure and development projects (Kleimeier and Megginson, 2000). These projects consist of two main phases, construction and operation (Soge, 2004). The construction phase is prone to technological and environmental risks. The operation phase is prone to market and political risks. As these problems arise during the project, banks become the target of multiple public campaigns which aggravate as banks are more active in project finance lending. In the case of the Equator Principles, BankTrack is a support organization responsible for promoting changes in banks' financing activities such that banks are held accountable toward

\footnotetext{
${ }^{1}$ For a comprehensive list of the banks that have adopted the Equator Principles through 2010, see Appendix B.
} 
environmental and societal damages. BankTrack monitors and publishes projects led by banks with a potentially high and negative impact on the environment, society, or both. Through these public campaigns, banks experience public pressure to change their lending behavior. As argued in the theory section, banks may then be more likely to react to such public pressure by adopting the Equator Principles.

Due to their large scale, project finance loans require large amounts of capital. As a consequence, project finance loans are often syndicated. Loan syndication refers to the joint issuance of loans by more than one bank. ${ }^{2}$ Banks in a loan syndicate are either lead arrangers or participants. Lead arrangers are the most active banks in the syndicate because they are responsible for establishing a relationship with the firm, negotiating the loan terms, guaranteeing an amount for a price range, and monitor the borrower (Sufi, 2007; Gopalan, Nanda, and Yerramilli, 2011). ${ }^{3}$

By forming a syndicate, banks diversify their loan portfolio, share risk and (monitoring) skills, and can more easily meet capital constraints (Simons, 1993; Ivashina and Scharfstein, 2010; Dennis and Mullineaux, 2000). In a syndicate with lead arrangers having different knowledge, experience, expertise, and specializations, lead arrangers can leverage each other's skills with the purpose of reducing information asymmetries in the loan arrangement process (Tykvova, 2007; Sufi, 2007; Champagne and Kryzanowski, 2007; Godlewski, Sanditov, and Burger-Helmchen, 2012; Alexy, Block, Sandner, and TerWal, 2012).

The most important costs associated with loan syndication result from agency problems causing differences in the effort banks exert when arranging loans, in particular when the differences in skills and competence levels among syndicate members are substantial (Gopalan, Nanda, and Yerramilli, 2011; Holmström, 1979, 1982; Panyagometh and Roberts, 2002; Lee and Mullineaux, 2004; Tykvova, 2007). For example, if a member of a syndicate is much more competent (i.e., has better knowledge, more experience, etc.) than another, the latter may free ride with the former exerting more effort in the syndication process.

For banks that have adopted the Equator Principles, competence and effort sharing through syndication are particularly important because of the due diligence the Equator Principles require. Banks that adopt the Equator Principles follow the International Finance Corporation (IFC)'s safeguard policies and the World Bank's Pollution Prevention

\footnotetext{
${ }^{2}$ For a background on loan syndication, see Dennis and Mullineaux (2000).

${ }^{3}$ Participants are passive syndicate members whose contribution is limited to funding the loan. See Sufi (2007) for more information about the tasks that lead arrangers and participants perform during the loan syndication process.
} 
program (Scholtens and Dam, 2007). In general, banks categorize projects, conduct social reviews, and perform due diligence of the projects they are to finance. ${ }^{4}$ According to the Equator Principles, projects to be financed are classified into one of three categories: A, B or C. Category A projects have a "potentially significant adverse social or environmental impact that is diverse, irreversible or unprecedented" (The Equator Principles Association, 2015). Category B projects have a potentially limited adverse social or environmental impact that are site-specific, mostly reversible and can be mitigated. Last, Category $\mathrm{C}$ projects have a minimal or no social or environmental impact (The Equator Principles Association, 2015).

When a project falls in either category $\mathrm{A}$ or $\mathrm{B}$, banks conduct social reviews and perform due diligence. Social reviews involve affected stakeholders, clients, as well as independent environmental and social consultants assisting in the project review and assessment. Overall, banks prepare a set of assessment documents, management systems and plans. First, banks have to identify and address the project's potential risks and impact through an Environmental and Social Impact Assessment (ESIA). ${ }^{5}$ In addition, audits regarding human rights, pollution standards, design criteria and/or construction standards may need to be conducted. As financing may originate in different countries with different legal systems, countries are classified into Designated or Non-Designated countries. ${ }^{6}$ For projects in non-designated countries, the Equator Principles require adherence to the International Finance Corporation (IFC)'s Performance Standards on Environment and Social Sustainability and the World Bank Group Environmental, Health and Safety Guidelines. For projects in designated countries, the Equator Principles requires adherence to the laws, regulations and permits pertaining social and environmental issues of the host country.

Next, the borrower of the loan also known as the client, prepares an Environmental and Social Management Plan (ESMP). As part of this plan, the client engages stakeholders to address and mitigate potential issues identified in the assessment process. In addition, independent environmental and social consultants participate in the process by assessing the documentation and systems put together by the banks and the borrower. Finally,

\footnotetext{
${ }^{4}$ The Equator Principles Association provides minimum standards to be followed by the banks adopting the principles and at their discretion, banks may apply additional requirements when financing projects.

${ }^{5}$ ESIA documents are partly or fully available online.

${ }^{6}$ The list of designated and non-designated countries can be found on the Equator Principles Association's website.
} 
banks prepare public reports on their Equator Principles implementation processes and experiences at least once per year.

In practice, it is common to observe project finance loans being syndicated by a mix of banks that have adopted the Equator Principles and banks that have not adopted the Equator Principles. Since adopters of the Equator Principles are committed to the regulation and non-adopters are not, syndication by banks suggests that adopters exert more effort when jointly lending with a non-adopter of the Equator Principles because of the due diligence they are required to conduct. Hence, we conjecture that syndication of project finance loans by banks that have adopted the Equator Principles and banks that have not leads to an effort asymmetry between adopters and non-adopters.

As a result, we expect a bank that has adopted the Equator Principles and syndicates a project finance loan, with a bank that has not adopted the Equator Principles, to pressure the non-adopter. In this way, the adopter can reduce effort in future syndicate collaborations while contributing to the legitimization of the principles by increasing the number of adopters. We refer to this behavior as peer pressure.

In sum, the emergence of the Equator Principles as a form of self-regulation is a response by banks to public pressures for stricter regulation in bank lending. If adopting the Equator Principles, banks reduce the information asymmetries regarding their lending practices in project finance by committing to "[...] implementing the [Equator Principles] in their internal environmental and social policies, procedures and standards for financing projects and $[\ldots]$ not provid[ing] $[\mathrm{p}]$ roject $[\mathrm{f}]$ inance $[\ldots]$ where the client will not, or is unable to, comply with the [Equator Principles]" (The Equator Principles Association, 2015). Hence, with a mix of banks that have and have not adopted the Equator Principles working together in loan syndicates, effort asymmetries in the loan syndication process arise. These effort asymmetries result from the due diligence adopters of the Equator Principles have to conduct. In an attempt to reduce effort asymmetries, adopters of the Equator Principles may exert peer pressure on the non-adopting banks. Therefore, the adoption of the Equator Principles is a clear example of the adoption of self-regulation in a context where firms collaborate. 


\section{Empirical framework}

We have conjectured that self-regulated firms, when collaborating with non-self-regulated firms, may opt to exert peer pressure on the non-self-regulated firm with the purpose to reduce any effort asymmetries. In particular, we are interested in the event of a bank adopting the Equator Principles given that it collaborates with a bank that has adopted the Equator Principles and possibly exerts pressure on its peer bank with the purpose of reducing effort asymmetries in their collaboration. There are three conditions we require from our empirical setup. First, we want to account for banks that have not yet adopted the principles, but may nevertheless do it later at some unknown time. Second, we want to recover an estimate of the speed of adoption. Third, we want to account for the development in the syndicated lending market as environmental changes into our specification model.

In order to model the event of a bank adopting the Equator Principles, we therefore estimate a Cox proportional hazards model, which fulfills all three conditions. Equation (1) summarizes our empirical setting:

$$
\lambda_{i}(t)=\lambda_{0}(t) \exp \left[\beta_{p p} \text { Peer Pressure } i j+\beta_{c} \text { Controls }\right],
$$

where the left-hand side term in Equation (1) is the hazard of bank $_{i}$ adopting the Equator Principles. On the right-hand side of the equation, we find a baseline hazard function, a set of covariates, and a set of coefficients to be estimated. The first term on the right-hand side, $\lambda_{0}(t)$, is the baseline hazard, a time-dependent unspecified term that allows environmental changes to be treated as an arbitrary function of time. The set of covariates includes Peer Pressure $_{i j}$, which is our proxy for our main hypothesis, and a group of controls to be explained in greater detail in the next paragraphs. $\beta_{p p}$, and $\beta_{c}$ are coefficients explaining the effects of Peer Pressure $i j$, and controls on bank $_{i}$ 's likelihood of adopting the Equator Principles, respectively. Although we exclude all time subscripts for ease of exposition, it is important to note that our covariates are time-varying, and they are measured for the same time period, unless otherwise specified.

Our main covariate is called Peer Pressure $i j$. According to our hypothesis, the peer

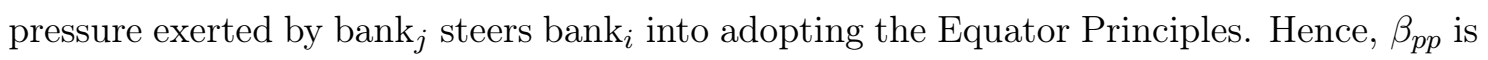
an estimate of the propensity of $\operatorname{bank}_{i}$ with Peer Pressure $i j$ to adopt the Equator Principles, 
and we expect $\beta_{p p}$ to have an effect greater than one, that is, a positive effect toward the adoption of the principles. We measure Peer Pressure $i j$ as the concentration of bank ${ }_{j}$ 's collaborations with $\operatorname{bank}_{i}$, given that bank $_{j}$ is an adopter of the Equator Principles. In the context of our empirical framework, the mechanism underlying peer pressure can be explained as follows: if bank $_{j}$ is an adopter of the Equator Principles and collaborates with bank $_{i}$, and the collaboration between bank $j$ and bank $_{i}$ intensifies, then the effort asymmetry between bank ${ }_{j}$ and $b b_{k}$ increases. It increases because every time bank $_{i}$

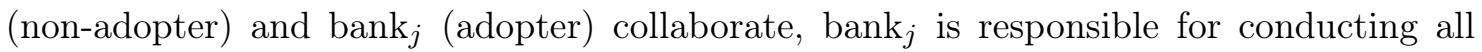
due diligence required by the Equator Principles Association. That is, bank ${ }_{j}$ exerts more effort in the loan arrangement process than bank $_{i}$ every time they collaborate. Therefore, in an attempt to reduce these effort asymmetries, $b_{a n k}$ is expected to exert peer pressure on bank $_{i}$ into adopting the Equator Principles as well.

Equation (2) below shows how Peer Pressure $_{i j}$ is calculated:

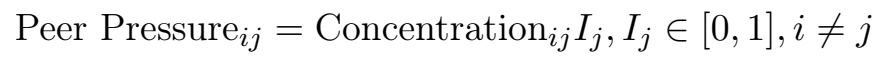

where $I_{j}$ is an indicator variable equal to one when $\mathrm{bank}_{j}$ is an adopter of the Equator Principles and equal to zero otherwise. To measure the intensity of the collaboration between bank $_{i}$ and bank $_{j}$, we define a variable called Concentration $i j$ corresponding to the ratio between the number of joint loan syndications between $b_{a n k}$ and $b_{a n k}$ to the total number of syndications bank ${ }_{j}$ has been involved in. Thus, Peer Pressure $i j$ is greater than zero only when $\operatorname{bank}_{i}$ and $b_{a n k}$ collaborate through loan syndications and when $\operatorname{bank}_{j}$ is an adopter of the Equator Principles.

We employ a set of controls to capture various other elements affecting the syndication process and the likelihood for adopting the Equator Principles. These controls include Number of Project Finance Loans $i$, Equator Bank ${ }_{j}$, Number of Equator Relationships ${ }_{i}$, Concentration $_{i j}$, Public Pressure ${ }_{i}^{t-1}$, and Country ESG . $_{\text {. }}$

Our first control, Number Project Finance Loans $i$, is the number of project finance loans arranged by bank ${ }_{i}$. Equator Bank ${ }_{j}$ is an indicator variable that is expected to be equal to one if peer bank $\mathrm{b}_{j}$ is an adopter of the Equator Principles and zero otherwise. We control for a bank's level of project finance lending because of two main reasons. First, as banks arrange more project finance loans, the possibility of financing a project going astray increases. Therefore, adoption of the Equator Principles may serve as a way to prevent or 
correct any damages from public campaigns against the bank. Second, as banks become responsible for more project finance loans, they become the key players in the market placing themselves as the focal point of public criticisms in case their lending activities become the targets of public campaigns. To capture a collective form of peer pressure also possibly increasing the likelihood of adopting the Equator Principles, we include Number of Equator Relationships as the number of unique syndicate collaborations bank ${ }_{i}$ has with adopters of the Equator Principles.

In addition, we control for the public pressures banks may experience which may also increase their adoption of the Equator Principles. Our control variable, Public Pressure ${ }_{i}^{t-1}$ measures whether a bank has been the target of public campaigns led by BankTrack. We obtain such information from BankTrack's website, which reports banks' financing activities of projects posing social and/or environmental challenges if implemented and

labels them as "dodgy deals." Public Pressure ${ }_{i}^{t-1}$ is then equal to one if $\operatorname{bank}_{i}$ is listed as the financier of a "dodgy deal" at time t-1 and zero otherwise.

Finally, a bank operating in a country with a weaker environmental, social and governance transparency may be more inclined to adopt the Equator Principles to complement the lack of existing regulation. We therefore use Bloomberg's Environmental, Social and Governance (ESG) reporting transparency measures for the country in which bank ${ }_{i}$ is headquartered.

\section{Data}

The Loan Pricing Corporation's DealScan database provides us with data on global corporate loans, which also include data on syndicated loans. DealScan is the main data source for research in syndicated lending (Dennis and Mullineaux, 2000; Sufi, 2007; Champagne and Kryzanowski, 2007; Francois and Missonier-Piera, 2007; Gatti, Kleimeier, Megginson, and Steffanoni, 2013; Godlewski and Weill, 2008; Godlewski, Sanditov, and Burger-Helmchen, 2012; Gopalan, Nanda, and Yerramilli, 2011; Ivashina and Scharfstein, 2010; Jones, Land, and Nigro, 2005). Since the Equator Principles were drafted in 2003, we collect data on loan originations from 2003 through 2010. The data provided by DealScan allows us to observe the syndicate structure of these loans. In line with Sufi (2007) we identify lead arrangers from DealScan's "Lead Arrangers" field or —if missing — from the banks listed with a lead role in the "All Lenders" field. Adopters of the Equator Principles are 
identified among these lead arrangers taking their year of adoption into account. ${ }^{7}$

\section{The adopters of the Equator Principles}

In order to understand the differences in lending activities, we compare the banks that have adopted the Equator Principles to the banks that have not adopted the Equator Principles. Table 1 compares the key characteristics between adopters and non-adopters of the Equator Principles. Between 2003 and 2010, the typical bank adopting the Equator Principles arranges larger loan amounts and more loans. On average, adopters of the Equator Principles arrange 123.77 loans, and close to one project finance loan on a yearly basis. Non-adopters only arrange 15.46 loans, with an average of 0.11 project finance loans, between 2003 and 2010. This suggests that while the number of banks adopting the Equator Principles is not large, they are the most active banks in the loan market.

An interesting aspect is that project finance loans make up only two percent and one percent of the lending portfolios for non-adopters and adopters, respectively. ${ }^{8}$ On the face of it, adopting the Equator Principles thereby does not appear to be driven by the materiality of project finance lending for these banks.

Since adopters of the Equator Principles syndicate more loans, we expect them to collaborate with more banks as well. Indeed, adopters of the Equator Principles collaborate almost ten times more than non-adopters both with fellow lead arrangers and with any bank in any particular role, as variables Number of Lender Collaborations and Number of Arranger Collaborations indicate.

[Insert Table 1 here]

The picture that emerges from Table 1 is similar to the one drawn by Scholtens and Dam (2007): the number of banks adopting the Equator Principles is small yet the impact of adoption is large. Additional support for this finding is provided in Table A1 in the Appendix, which presents yearly project finance league tables for years 2003-2010. These league tables show the top 10 banks in terms of their lending activity within the project finance lending market. Adopters of the Equator Principles are marked with an asterisk $(*)$ in these league tables.

\footnotetext{
${ }^{7}$ We focus on lead arrangers as they, rather than the passive participants, need to collaborate and might thus experience peer and external pressures.

${ }^{8}$ This is based on the measure Project Finance Concentration calculated as the ratio between the share of the project finance loans arranged over the share of all loans arranged. Share is calculated as the loan size divided by the number of lead arrangers in the syndicate.
} 
By 2008, the number of adopters has not only increased, but adopters occupy the top positions in the league table. ${ }^{9}$ With the market share of adopters starting at $47 \%$ in 2005 , this market share reaches a peak in 2008 with $64 \%$ and by 2010 , it equals $68 \%$.

In order to delve into the geographical patterns in the adoption of the Equator Principles, we refer to Table 1, which displays the country of origin of the adopters in our sample. Adopters come from 22 different countries in North America, South America, Europe, Africa/Middle East, and Asia and Oceania. Most of the adopters are concentrated in Europe, and South America has the fewest number of adopters. From Table A2 in the Appendix, we learn that the Netherlands leads in terms of adoption, followed by Canada, France, the U.S. and U.K. ${ }^{10}$ Whereas the U.K. has the largest number of early adopters, French banks are slow in adopting. Although they started fairly late, countries such as Brazil, Spain and South Africa, each also headquarter a fair number of adopters.

\section{Lead arranger collaboration network characteristics}

In order to study the peer pressure effects adopting banks exert on non-adopting banks, we focus on bank-pair syndication relationships and we study them through an observation period of eight years. The bank for which we measure adoption is referred to as bank and the bank that possibly exerts peer pressure is referred to as bank $\mathrm{b}_{j}$. Because $\mathrm{bank}_{i}$ and bank $_{j}$ may not syndicate loans every year in our observation period, our panel of observations is unbalanced.

To estimate the survival probabilities of adopting the Equator Principles, only banks active in syndicating project finance loans, that is, banks jointly arranging at least one project finance loan between 2003 and 2010, enter the study. We exclude bank ${ }_{i}$ if not active in the project finance loan market as it has no intrinsic need or interest in adopting the Equator Principles, and we also exclude banks that do not jointly arrange loans with others as they are not subject to peer pressures. In contrast, we consider all bank $i^{-}$ bank $_{j}$ collaborations, irrespective of whether bank ${ }_{i}$ and $b^{2} k_{j}$ collaborate through project

\footnotetext{
${ }^{9}$ We calculate the market share of adopters as the total project finance loan amount arranged by adopters of the Equator Principles within the league table divided over the total project finance loan amount arranged by all banks in the league table.

${ }^{10}$ The data reported in this table has been collected from the Equator Principles Association's website and it includes information like the country of origin of adopters and year of adoption. Note that the number of adopters by country may differ between the ones reported in Table A2 and our sample because our sample includes those banks that are active in project finance and report their lending activities to Loan Pricing Corporation for publication in their DealScan database. Therefore, we have fewer banks in our sample.
} 
finance or any other type of syndicated loans. This reflects our belief that bank $\mathrm{b}_{j}$ exerts

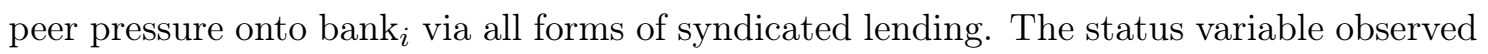
in our survival estimation indicates whether bank ${ }_{i}$ has adopted the Equator Principles. We censor bank ${ }_{i}$ if it has not adopted the Equator Principles.

[Insert Table 2 here]

Table 2 presents the summary statistics of the covariates used in our survival model. Among the total of 41,403 bank-pairs that co-arrange loans between 2003 and 2010, the average bank $_{i}$ receives a peer pressure equal to $1 \%$. That is, the average bank that arranges project finance loans makes up $1 \%$ of the portfolio of collaborations of $b^{2} k_{j}$, which has adopted the Equator Principles. While this average is low, the impact on the adoption of the Equator Principles is large because $4 \%$ of all bank $_{i}$ 's receive a peer pressure of $50 \%$ or more. This suggests that bank syndications are diffused throughout the network formed by the banks in our sample; nevertheless, some of these syndications are highly concentrated. On average, however, a bank ${ }_{i}$ collaborates with slightly more than 20 adopters, as shown by the variable Number of Equator Relationships ${ }_{i}$ in Table 2.

We observe that the level of project finance activity by banks is highly skewed with a median of four and an average of 12.98 project finance loans, respectively, and with some banks partaking in a substantial number of project finance loans that can reach up to 124 loans in a given year. On average, $21 \%$ of all banks active in project finance arrange receive public pressure from BankTrack because one or more the projects they finance are classified as "dodgy" and published on BankTrack's website. In terms of geographical characteristics, we classify banks by the country in which they are headquartered according to Bloomberg's 2010 Environmental, Social and Governance (ESG) country classification. ${ }^{11}$ Higher ESG country scores correspond to countries with better Environmental, Social and Governance data disclosure as measured in Bloomberg's Sustainability Survey. While in theory these scores can reach a maximum value of 100 for countries with a complete data disclosure, the highest score in our sample is 63.58 and it corresponds to Sweden. On average, the banks in the study come from a country with an ESG profile of 53.72, a value close to the one assigned to countries like Mexico or Israel. The lowest score in our sample is equal to 33.41 and it corresponds to Saudi Arabia.

\footnotetext{
${ }^{11}$ Bloomberg released its country ESG scores in 2009. Since scores are fairly time invariant over the short time window, we choose to only use ESG scores for year 2010.
} 


\section{Results}

Our main aim is to find out whether peer pressure influences the likelihood of adopting the Equator Principles, its implications, and to see how robust peer pressure is in the presence of other types of pressure banks may experience when syndicating loans.

We begin by estimating the effect of peer pressure. Table 3 contains the hazard estimates of bank $_{i}$ adopting the Equator Principles in the presence of Peer Pressure ${ }_{i j}$, and a set of six controls: Number of Project Finance Loans $i$, Number of Equator Relationships, Public Pressure $_{i}^{t-1}$, Country $\mathrm{ESG}_{i}$, Concentration $_{i j}$, and Equator Bank ${ }_{j}{ }^{12}$

[Insert Table 3 here]

First, we estimate our base model, without accounting for a bank's public pressures or its country's ESG profile. The results of our base model are included in column (1) in Table 3. Next, we add the impact of public pressure in column (2), and the role of governance in bank $_{i}$ 's country of origin in column (3). In column (4) we include both variables, Public Pressure $_{i}^{t-1}$ and Country ESG . When comparing the effect Peer Pressure $_{i j}$ has in the different specifications, we observe that it is very similar in sign, magnitude, and significance. The hazard rate for Peer Pressure $i j$ is greater than one and statistically significant implying that peer pressure does result in $\mathrm{bank}_{i}$ adopting the Equator Principles.

Of all the reported specifications in Table 3, column (4) contains our most complete model and explains $13.42 \%$ of the variation in the hazard of the adoption of the Equator Principles. We therefore focus our discussion on the results reported in column (4).

Through peer pressure, $\operatorname{bank}_{j}$, an adopter of the Equator Principles, is able to influence bank $_{i}$ into adopting the principles as the hazard ratio of 2.575 reflects. This finding supports our main hypothesis. In order to assess the relevance peer pressure on the adoption of self-regulation, we calculate the relative risk for varying values of Concentration $i j$ both when bank ${ }_{j}$ is an Equator Bank and when it is not. ${ }^{13}$ We find that when bank $_{i}$

\footnotetext{
${ }^{12}$ Recall that in our estimates, the time-varying likelihood of adopting the Equator Principles is proportional to an unspecified baseline hazard function (Cox, 1972). To estimate the hazard model in this manner, we have to assume that the covariates are proportional to the baseline hazard function. We tested this assumption in two ways. First, we look at the martingale residuals following Lin, Wei, and Ying (1993). We fit an observed empirical score process based on martingale residuals. Then, based on 1,000 random simulation paths, we draw an empirical score process and compare the simulated and observed scores. Since they are not different from each other, we cannot reject the proportionality assumption. Second, we use Schoenfeld Residuals, calculated as the difference between the covariate value for observation $i$ and its expected value, where observation $i$ experiences the event (adopts the Equator Principles). We then test these residuals for time independence, and we find that since they are indeed independent of time, the proportionality assumption holds.

${ }^{13}$ Relative risk is calculated as follows: $\frac{\lambda_{0}(t) \exp \left(\phi \beta_{p p}\right)}{\lambda_{0}(t) \exp \left(\psi \beta_{p p}\right)}$, where $\phi \in \mathbb{R}$ and $\psi \in \mathbb{R}$ are the values for which the
} 
collaborates with an Equator $\mathrm{Bank}_{j}$ and this collaboration concentration increases by one standard deviation, or by 0.03, bank $_{j}$ will adopt the Equator Principles at a rate of $8 \%$. As collaborations become more concentrated and increase by two and three standard deviations, or by 0.06 and 0.09 , the likelihood of adopting the Equator Principles is $16.7 \%$ and $26.1 \%$, respectively. In other words, as peer pressure increases, the likelihood of adopting the Equator Principles increases as well.

While banks arranging a large number of project finance loans may be more likely to adopt the Equator Principles, we do not find any significant effect. And, even with a statistically significant hazard rate equal to 1.002 in specifications (1) and (3), we can conclude that the number of project finance loans arranged has a minimal effect in the adoption of the Equator Principles: for each additional project finance loan bank arranges, the likelihood of adopting the Equator Principles increases by only $0.20 \%$, all else equal. For this type of pressure to be meaningful, say resulting in an increase in the likelihood of adopting the Equator Principles of $5 \%$, bank $_{i}$ has to increase the number of project finance loans it arranges by 20 loans in any given year. This increase is sizable given that the $75^{t h}$ percentile corresponding to the number of project finance loans banks arrange is only equal to 15 .

The multiple collaborations $\operatorname{bank}_{i}$ has with other Equator banks, proxied by the variable Number of Equator Relationships $i$, may influence a bank's tendency to become selfregulated. According to the results presented in Table 3, these collaborations indeed increase the likelihood of adopting the Equator Principles, with a hazard ratio of 1.068. Since the average bank $_{i}$ collaborates 20 adopters through multiple other loans, we can calculate the sensitivity an increase in these collaborations has on adoption. ${ }^{14}$ For a bank not collaborating with adopters of the Equator Principles, arranging a loan with a single adopter increases the likelihood of adoption by $1 \%$. This relative hazard increases to $6 \%$, $9 \%$, and $12 \%$ as the number of equator relationships increases to two, three and four, respectively. However, the relative hazard plateaus once the change in the number of collaborations is greater than four, demonstrating that there are decreasing returns to scale to this type of pressure.

Banks being targets of public campaigns experience a public pressure influencing their adoption of the Equator Principles. In fact, banks encountering public pressures from

${ }^{14}$ From Table 2, we observe that the number of Equator relationships ranges from 0 to 49. 
BankTrack have a $34.1 \%$ higher likelihood of subsequently adopting the Equator Principles as opposed to banks not receiving such public pressures. It appears that the adoption of the Equator Principles as a form of damage control is a rather popular strategy by banks.

Interestingly, banks headquartered in countries with (other) strict ESG rules are less likely to adopt the Equator Principles, although to a lower extent. For example, all else equal, a bank headquartered in Sweden (with the maximum ESG score of 63.58) is 2.5\% less likely to adopt the Equator Principles than a bank headquartered in Mexico (with an ESG score close to the sample average and equal to 54.09). Even when we compare a Swedish bank to a bank headquartered in Saudi Arabia (with the minimum ESG score of 33.41), the difference in the likelihood of adoption is a mere $7.6 \%$.

In sum, we find that adoption rates increase with the relative intensity that a nonadopter collaborates with an adopter (peer pressure), the absolute intensity that a nonadopter collaborates with an adopter (Collaborations $i j$ ), and the number of different adopters that a non-adopter collaborates with. We conclude that self-regulation will spread more quickly and become the standard in an industry that is more interconnected. For policy makers this suggests that self-regulation is a good strategy for highly-connected industries, whereas, explicit or mandatory regulation may be a better choice for industries in which firms collaborate less closely and intensely.

Since we are assessing the impact of peer pressure on adopting self-regulation, it is of particular interest to study the effects of the accumulation of pressure. In order to do so, we use our survival analysis model to dig deeper into the time patterns of adoption. Figure 2 presents the survivor function for $\operatorname{bank}_{i}$ adopting the Equator Principles when all covariates are equal to the average. The $\mathrm{x}$-axis in this figure is the observation period. Since the survival model that we estimated considers adoption of the Equator Principles as the event of interest, survival in this context implies no adoption of the Equator Principles. Therefore, a survivorship close to one indicates no adoption and lower survivorship rates indicate adoption.

\section{[Insert Figure 2 here]}

The survivor function in Figure 2 illustrates how pressure builds up: we can see that survival rates decrease (adoption of the Equator Principles increases) as the observation period increases. For example, we see that in the first two periods (years) of observation, adoption does not occur. However, adoption then increases to $40 \%$ after the third time 
period, and ends with a $92.5 \%$ adoption likelihood by the end of the eight observation time periods. This means that for a $\operatorname{bank}_{i}$ whose covariates are equal to the average, likelihood of adopting the Equator Principles increases from zero to $92.5 \%$ after eight years. In other words, bank ${ }_{i}$ adopts the Equator Principles with a rate of $92.5 \%$ after eight years of receiving peer pressure of $1 \%$, social pressure of 12.98 , collective peer pressures of 19.59 , while collaborating with an adopter of the Equator Principles $23 \%$ of the time. In reality, it is rare that a bank is the subject of all types of pressure at the same time, which explains why actual adoption rates are much lower.

\section{Robustness}

The extent to which firms feel pressured into adopting self-regulation may be different in extreme situations, encountered by only very few firms. In order to find out whether such extreme situations drive our results, we now delve into three of those extreme situations for $\operatorname{bank}_{i}$. First, we focus on banks extremely active in project finance. Next, we focus on banks operating in regions where the Equator Principles are extremely popular. Finally, we focus on banks experiencing extreme peer pressure.

\section{Activity levels in project finance arrangement}

In the syndicated loan market for project finance, not all banks are equal. As evidenced by the existence of league tables such as in Table A1, some banks are particularly active, acting as the spiders in the syndicated lending web. Consequently, to find out whether these active banks drive our results, we repeat our analysis, but this time we explicitly account for whether banks are very active, or less active in project financing.

In order to conduct this complementary analysis, we include three additional (dummy) variables. Number of Project Finance Loans $i \leq 3$ indicates when a bank is in the lowest quartile of arranging activity in the market. Banks in the most active quartile are indicated with the variable Number of Project Finance Loans ${ }_{i} \geq 18$, and the second most active quartile is indicated by Number of Project Finance Loans ${ }_{i}>6$ and $<18$. The control group in our analysis is the second quartile, which is closest to the average. In order to fully understand the effects of project financing and peer pressure on the adoption of the Equator Principles, we interact our new indicators with our covariates Concentration $i j$ 
and Equator Bank $j$.

[Insert Table 4 here]

We find that Peer Pressure $i j$, remains robust throughout all four specifications reported in Table 4. As is to be expected, the impact of Number of Project Finance Loans ${ }_{i}$ is now significantly less than one suggesting that as banks arrange more project finance loans, the tendency to adopt the Equator Principles decreases. However, the effect is rather small at $0.3 \%$.

The main lesson learned from the results presented in Table 4 comes from what happens to those banks that are most and least active in project finance, respectively. We observe the likelihood of adoption in both groups being lower than for the benchmark average group. However, in order to accurately compare both groups, we need to take all cross terms into account. Doing so allows us to find that banks arranging less than three project finance loans have a $74 \%$ higher likelihood of adopting the Equator Principles than a bank arranging between six and 17 project finance loans. ${ }^{15}$ This suggests that the least active banks in the market are in fact more sensitive to peer pressure effects than the more active and established banks.

\section{Countries with a large numbers of banks adopting the Equator Prin- ciples}

The cumulative impact of peer pressure may not just manifest itself through repeated interactions with an adopter of the Equator Principles, but also in the aggregate. In order to find out how peer pressure fares in countries where the adoption of the Equator Principles is particularly common, we select a sub-sample of banks operating in those countries. We refer to Table A2 in the Appendix, and select Canada (seven adopters), The Netherlands (six adopters), Australia, Brazil, France, the U.K. and the U.S. (four adopters each), and Japan and South Africa (three adopters each). Table 5 presents the results.

[Insert Table 5 here]

Indeed, the impact of peer pressure is higher for this sample. Our independent variable, Peer Pressure ${ }_{i j}$, remains robust throughout all specifications. The likelihood of peer pressure in adopting the Equator Principles, given that there is a collaboration with an

\footnotetext{
${ }^{15}$ For regression 4 , the relative risk is calculated as follows: $\frac{\lambda_{0}(t) \exp \left[\log _{2.72}(9.193) \times 1 \times \operatorname{Concentration}_{i j}+\log _{2.72}(0.548) \times 1\right]}{\lambda_{0}(t) \exp \left[\log _{2.72}(22.451) \times 1 \times \operatorname{Concentration}_{i j}+\log _{2.72}(0.301) \times 1\right]}$
} 
adopter of the Equator Principles is $62.5 \%$ higher than in the absence of such a collaboration. ${ }^{16}$ Meanwhile, the effect of all other variables remain robust with the exception of the Number of Project Finance Loans $i$, which now has a hazard rate less than one but its effect is marginally small.

\section{Extreme peer pressure}

Our final robustness test concerns the impact of extreme peer pressure on the likelihood of adopting the Equator Principles. In order to study this, we have to re-assemble our dataset. In our analysis so far, we have studied pairings between banks over time. Now, we wish to measure extreme peer pressure, i.e. the maximum amount of pressure a bank receives in a given year from all the banks with whom it collaborates.

We thereby redefine our measure for peer pressure as follows: ${ }^{17}$

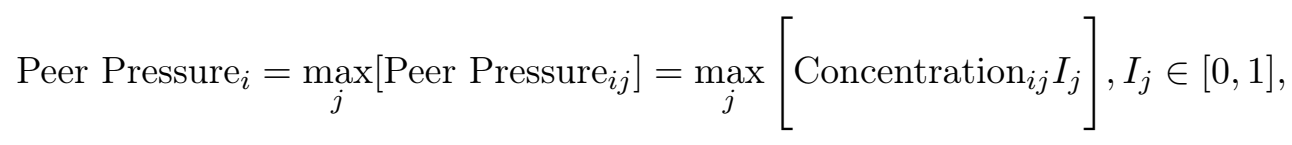

where Peer Pressure ${ }_{i}$ now corresponds to the maximum peer pressure bank i $_{i}$ receives from all its collaborations with adopters of the Equator Principles. Certainly, when bank ${ }_{i}$ col-

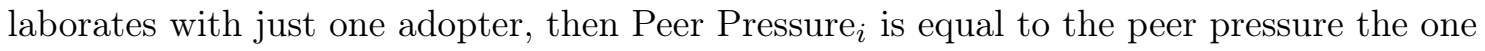
adopter exerts. When bank $_{i}$ does not collaborate with any adopters, then Peer Pressure $i$ is equal to zero. In order to be consistent, we also redefine Equator $\mathrm{Bank}_{j}$ as an indicator variable equal to one if $\operatorname{bank}_{i}$ has any collaborations with adopters of the Equator Principles, and zero otherwise. We now define Concentration ${ }_{i j}$ as the maximum concentration

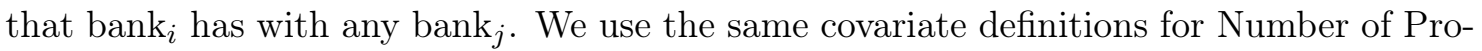
ject Finance Loans $i$, Number of Equator Relationships $i$, Public Pressure ${ }_{i}^{t-1}$, and Country $\mathrm{ESG}_{i}$ as these covariates pertain to bank $_{i}$ only.

[Insert Table 6 here]

From Table 6, we learn that the impact of peer pressure almost doubles when we focus on extreme peer pressure. The Number of Project Finance Loans $s_{i}$ is no longer significant. Public pressure no longer plays a role in the adoption of the Equator Principles when peer pressure is at its maximum. Being headquartered in a country with a good ESG profile

\footnotetext{
$16 \exp \left[\log _{2.72}(1.819) \times 1-\log _{2.72}(0.093) \times 1\right]=0.5985-0.1132=1.6250$.
}

${ }^{17}$ Interestingly, although it may appear to pay a price for redefining peer pressure, a lower number of observations, we now are less susceptible of overestimating our standard errors. 
gains importance, but in this - more aggregate - analysis it appears to cover some of the other sources of pressure, such as that coming from collaborations with Equator banks which loses statistical significance when controlling for Country $\mathrm{ESG}_{i}$.

\section{Discussion}

The analysis presented in this study responds to an unexplored issue in the extant literature: the adoption of self-regulation by firms interacting through collaborations. Our findings support the idea that collaborating firms, and in our case collaborating banks, exert pressure on each other to reduce effort asymmetries by adopting self-regulation.

In order to explore the effect of the peer pressure mechanisms self-regulated firms exert on their non-self-regulated peers, we focus on the syndicated loan market in which banks may opt for self-regulation by adopting the Equator Principles and in which banks tend to collaborate by jointly syndicating loans. We find that as banks collaborate, pressure from adopters increases the likelihood of adopting the Equator Principles, as firms pressure their peers into becoming self-regulated.

We conjecture that the incentives for firms to pressure their peers into becoming selfregulated lies in the effort asymmetry that arises from the collaboration between selfregulated and non-self-regulated firms. We show that banks adopting the Equator Principles are tasked with extensive due diligence also requiring the involvement of the borrowing firm and external auditors. When a bank that has adopted the Equator Principles collaborates with a bank that has not adopted the principles, all the due diligence required by the Equator Principles Association is to be carried out by the adopter alone, i.e. the adopter is required to exert more effort. Hence, in an attempt to reduce such effort differences, the adopter exerts pressure on its peer bank such that the bank with whom it collaborates adopts the Equator Principles as well, and the effort asymmetry is reduced in future collaborations.

While in this research, we focus on the adoption of self-regulation, it should be clear that the results presented here apply to many other areas in which collaborations between firms are observed, including for example the adoption of technology, products, and strategic decision making.

However, how generalizable our results are depends among others on the specifics of both self-regulation and collaboration, respectively. First, it is important to study the 
benefits associated with the adoption of the of the Equator Principles and self-regulation in general. What is the shadow price of adopting the Equator Principles? Is adoption of the Equator Principles associated with the financial performance of the adopting bank? Are banks more inclined to adopt the Equator Principles as a way to correct their public image after being damaged and hurting their financial performance? Or are the betterperforming banks adopting the Equator Principles? A partial answer to these questions come from an analysis of the reaction of stock prices following the public announcement of banks adopting the Equator Principles. Scholtens and Dam (2007) conduct a similar study and find no effect on the stock returns following the adoption of the Equator Principles and argue this might be due to the small portion that project financing represents within a bank's loan portfolio.

All things considered, in this paper we studied self-regulation in a market in which firms collaborate. In particular, we studied self-regulation by banks in the syndicated loan market as they adopt the Equator Principles. We found that as banks adopt the Equator Principles, they exert peer pressure on their collaborating partners to adopt the principles as well, the reason being to reduce the effort asymmetries that arise from the collaboration between a self-regulated and a non-self-regulated firm. The approach that we propose here can be widely extended and adapted to explore other units of analysis and other types of adoptions besides self-regulation. 


\section{References}

Alexy, O., J. Block, P. Sandner, And A. TerWal (2012): "Social Capital of Venture Capitalists and Start-Up Funding," Small Business Economics, 39, 835-851.

Arora, S., And T. CASON (1995): "An Experiment in Voluntary Environment Regulation: Participation in EPA's 33/50 Program," Journal of Environmental Economics and Management, 28, 271-286.

Benabou, R., And J. Tirole (2006): "Incentives and Prosocial Behavior," American Economic Review, 96, 1652-1678.

Champagne, C., And L. Kryzanowski (2007): "Are Current Syndicated Loan Alliances Related to Past Alliances?," Journal of Banking \& Finance, 31(10), 3145-3161.

Cox, D. (1972): "Regression Models and Life Tables (with Discussion)," Journal of the Royal Statistical Society. Series B, 34, 187-220.

Demarzo, P., M. Fishman, and K. Hagerty (2005): "Contracting and Enforcement with a self-Regulatory Organization," Review of Economic Studies, 72, 687-706.

Dennis, S., And D. Mullineaux (2000): "Syndicated Loans," Journal of Financial Intermediation, 9, 404-426.

Diller, J. (1999): "A Social Conscience in the Global Marketplace? Labour Dimensions of Codes of Conduct, Social Labelling and Investor Initiatives," International Labor Review, 138, 99-129.

Esty, B., And A. Sesia (2005): "An Overview of Project Finance - 2004 Update," Harvard Business School Case Study, 9-205-065.

Francois, P., And F. Missonier-Piera (2007): "The Agency Structure of Loan Syndicates," Financial Review, 42, 227-245.

Gatti, S., S. Kleimeier, W. Megginson, And A. Steffanoni (2013): "Arranger Certification in Project Finance," Financial Management, 42(1), 1-40.

Godlewski, C., B. Sanditov, And T. Burger-Helmchen (2012): "Bank Lending Networks, Experience, Reputation and Borrowing Cost: Empirical Evidence from the French Syndicated Lending Market," Journal of Business Finance and Accounting, 39, $113-140$.

Godlewski, C., AND L. Weill (2008): "Syndicated Loans in Emerging Markets," Emerging Markets Review, 9, 206-219.

Gopalan, R., V. Nanda, and V. Yerramilli (2011): "Does Poor Performance Damage the Reputation of Financial Intermediaries? Evidence from the Loan Syndication Market," Journal of Finance, 66(6), 2083-2120.

Grajzl, P., And P. Murrell (2007): "Allocating Lawmaking Powers: Self-Regulation vs Government Regulation," Journal of Comparative Economics, 35, 520-545.

Holmström, B. (1979): "Moral Hazard and Observability," Bell Journal of Economics, $10,74-91$.

(1982): "Moral Hazard in Teams," Bell Journal of Economics, 13, 324-340.

Ivashina, V., And D. Scharfstein (2010): "Loan Syndication and Credit Cycles," American Economic Review: Papers and Proceedings, 100, 57-61. 
Jones, J., W. Land, And P. Nigro (2005): "Agent Bank Behavior in Bank Loan Syndication," Journal of Financial Research, 28, 385-402.

King, A., M. Lenox, And A. Terlaak (2005): "The Strategic Use of Decentralized Institutions: Exploring Certification with the ISO 14001 Management Standard," Academy of Management Journal, 48, 1091-1106.

Kleimeier, S., And W. L. Megginson (2000): "Are Project Finance Loans Different From Other Syndicated Credits?," Journal of Applied Corporate Finance, 13(1), 75-87.

Kolk, A., And R. van Tulder (2002): "The Effectiveness of Self-regulation: Corporate Codes of Conduct and Child Labour," European Management Journal, 20(3), 260-271.

LaPorta, R., F. L. De Silanes, A. Schleifer, and R. Vishny (1997): "Legal Determinants of External Finance," Journal of Finance, 52, 1131-1150.

Lee, S. W., And D. J. Mullineaux (2004): "Monitoring, Financial Distress, and the Structure of Commercial Lending Syndicates," Financial Management, 33, 107-130.

Lenox, M. J., And J. NASH (2003): "Industry Self-Regulation and Adverse Selection: A Comparison Across Four Trade Association Programs," Business Strategy and the Environment, 12, 343-356.

Lin, D., J. Wei, And Z. Ying (1993): "Checking the Cox Model with Cumulative Sums of Martingale-Based Residuals," Biometrika, 80(3), 557-572.

Maxwell, J., T. Lyon, and S. Hackett (2000): "Self-Regulation and Social Welfare: The Political Economy of Corporate Environmentalism," Journal of Law and Economics, 43, 583-618.

Nunez, J. (2001): "A Model for Self-Regulation," Economic Letters, 74, 91-97.

Panyagometh, K., And G. Roberts (2002): "Private Information, Agency Problems and Determinants of Loan Syndications: Evidence from 1987-1999," Working Paper.

Pistor, K., And C. Xu (2003): "Incomplete Law," Journal of International Law and Politics, 35, 921-1013.

Potoski, M., And A. Prakash (2005): "Green Clubs and Voluntary Governance: ISO 14001 and Firms' Regulatory Compliance," American Journal of Political Science, 49, $235-248$.

Scholtens, B., And L. Dam (2007): "Banking on the Equator. Are Banks that Adopted the Equator Principles Different from non-Adopters?," World Development, 35, 13071328.

Segerson, K., And T. Miceli (1998): "Voluntary Environmental Agreements: Good or Bad News for Environmental Protection?," Journal of Environmental Economics and Management, 36, 109-130.

Short, J., And M. Toffel (2010): "Making Self-Regulation More than Merely Symbolic: The Critical Role of the Legal Environment," Administrative Science Quarterly, 55, 361396.

Simons, K. (1993): "Why Do Banks Syndicate Loans?" New England Economic Review, January, $45-52$.

Soge, M. (2004): "The nature of credit risk in project finance," BIS Quarterly Review, 91, 91-101. 
Sufi, A. (2007): "Information Asymmetry and Financing Arrangements: Evidence from Syndicated Loans," Journal of Finance, 62(2), 629-668.

The Equator Principles Association (2015): "Equator Principles," Retrieved from http://www.equator-principles.com/.

Tykvova, T. (2007): "Who Chooses Whom? Syndication, Skills and Reputation," Review of Financial Economics, 16, 5-28.

van Tulder, R., And A. Kolk (2001): "Multinationality and Corporate Ethics: Codes of Conduct in the Sporting Goods Industry," Journal of International Business Studies, $32(2), 267-283$. 
A Appendix: Project Finance League Tables 


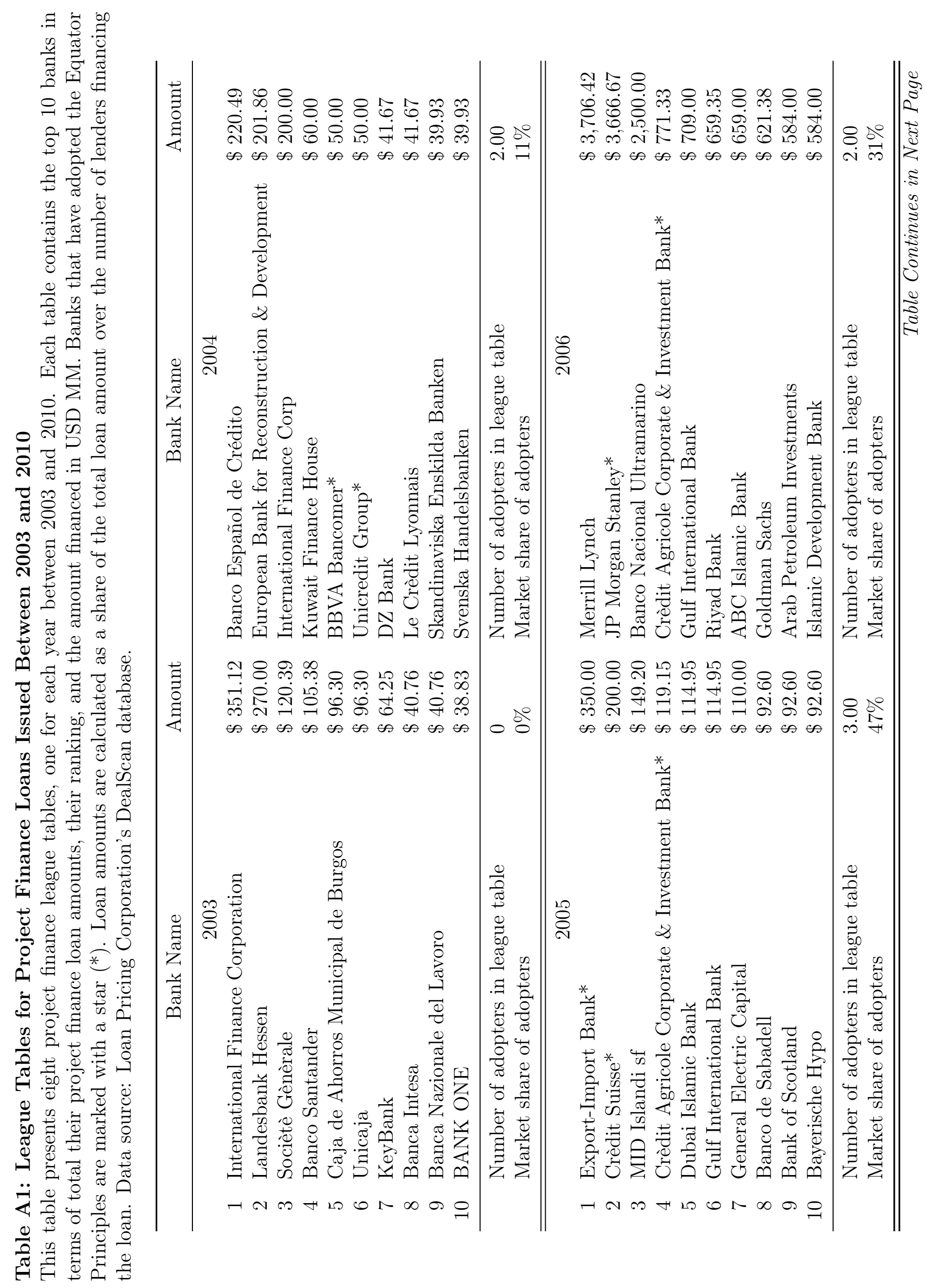




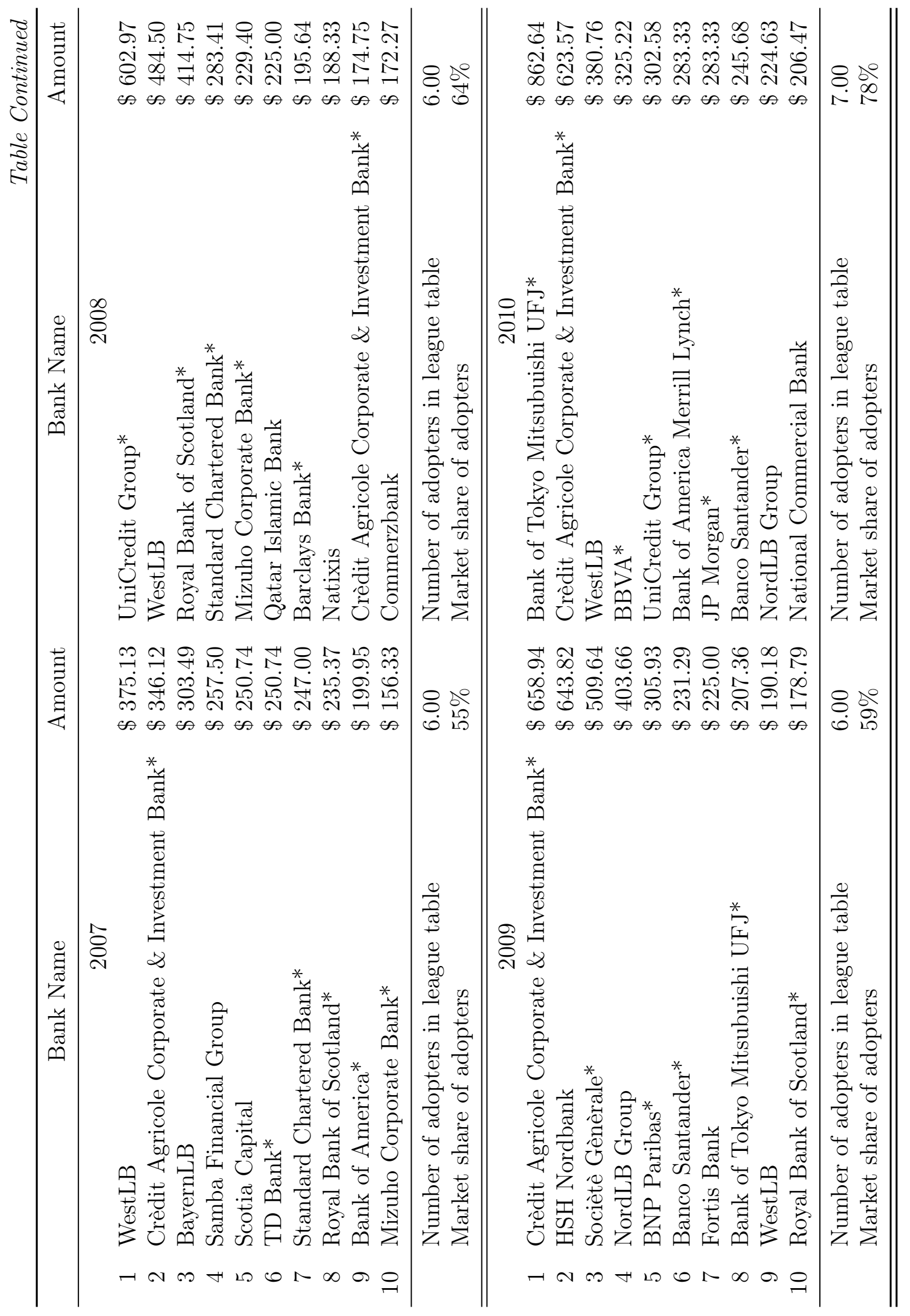




\section{B Appendix: Adopters of the Equator Principles}

Table A2: Adopters of the Equator Principles

\begin{tabular}{|c|c|c|}
\hline Year & Bank Name & Country \\
\hline \multirow[t]{14}{*}{2003} & Westpac Banking Corporation & Australia \\
\hline & Barclays & United Kingdom \\
\hline & Citigroup & United States \\
\hline & Crèdit Suisse Group & Switzerland \\
\hline & Crèdit Agricole & France \\
\hline & Rabobank & The Netherlands \\
\hline & Royal Bank of Scotland & Scotland \\
\hline & UniCredit Bank & Germany \\
\hline & ING Bank & The Netherlands \\
\hline & Royal Bank of Canada & Canada \\
\hline & HSBC & United Kingdom \\
\hline & Standard Chartered & United Kingdom \\
\hline & Mizuho Bank & Japan \\
\hline & Canadian Imperial Bank of Commerce & Canada \\
\hline \multirow[t]{6}{*}{2004} & KBC Group & Belgium \\
\hline & Eksport Kredit Fonden & Denmark \\
\hline & Banco Bilbao Vizcaya & Spain \\
\hline & Itaù Unibanco & Brazil \\
\hline & Banco Bradesco & Brazil \\
\hline & Manulife Financial & Canada \\
\hline \multirow[t]{6}{*}{2005} & Wells Fargo Bank & United States \\
\hline & Banco Espìrito Santo & Portugal \\
\hline & Bank of Montreal & Canada \\
\hline & FMO & The Netherlands \\
\hline & Nedbank & South Africa \\
\hline & Bank of Tokyo-Mitsubishi UFJ & Japan \\
\hline \multirow[t]{6}{*}{2006} & Banco do Brasil & Brazil \\
\hline & Bank of America & United States \\
\hline & Intesa Sanpaolo & Italy \\
\hline & Bank of Nova Scotia & Canada \\
\hline & JP Morgan & United States \\
\hline & ANZ & Australia \\
\hline
\end{tabular}

Table Continues in Next Page 
Table Continued

\begin{tabular}{lll}
\hline Year & \multicolumn{1}{c}{ Bank Name } & \multicolumn{1}{c}{ Country } \\
\hline 2007 & Nordea Bank & Sweden \\
& Banco de Galicia y Buenos Aires & Argentina \\
& CaixaBank & Spain \\
Skandinaviska Enskilda Banken & Sweden \\
CIFI & Costa Rica \\
TD Bank Financial Group & Canada \\
Corpbanca & Chile \\
Bank Muscat & Sultanate of Oman \\
Sociètè Gènèrale & France \\
Sumitomo Mitsui Banking Corporation & Japan \\
National Australia Bank & Australia \\
Export Development Canada & Canada \\
Banco de la República Oriental de Uruguay & Uruguay \\
Lloyds Banking Group & United Kingdom \\
KfW IPEX-Bank & Germany \\
DNB & Norway \\
BNP Paribas & France \\
Industrial Bank & China \\
Bancolombia & Colombia \\
Arab African International Bank & Egypt \\
Standard Bank & South Africa \\
Efic & Australia \\
Banco Santander & Spain \\
Access Bank Plc & Nigeria \\
FirstRand & Africa \\
ABN Amro & The Netherlands \\
ASN Bank & The Netherlands \\
CAIXA Economica Federal & BMCE Bank & Brazil \\
NIBC Bank & Morocco \\
Natixis & The Netherlands \\
\hline \hline & & France \\
\hline
\end{tabular}




\section{Figures and Tables}

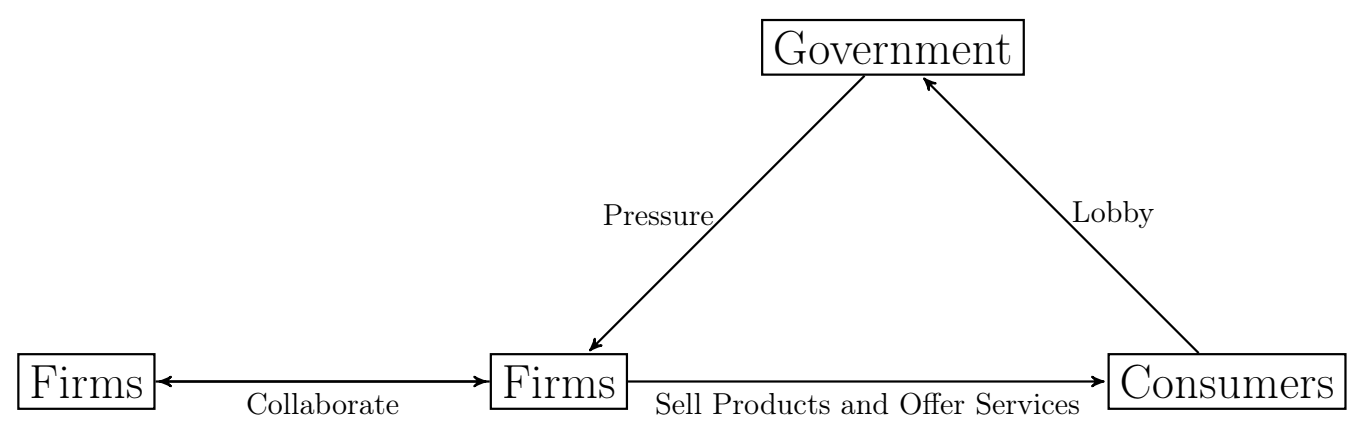

Figure 1: A framework for the adoption of codes of conduct

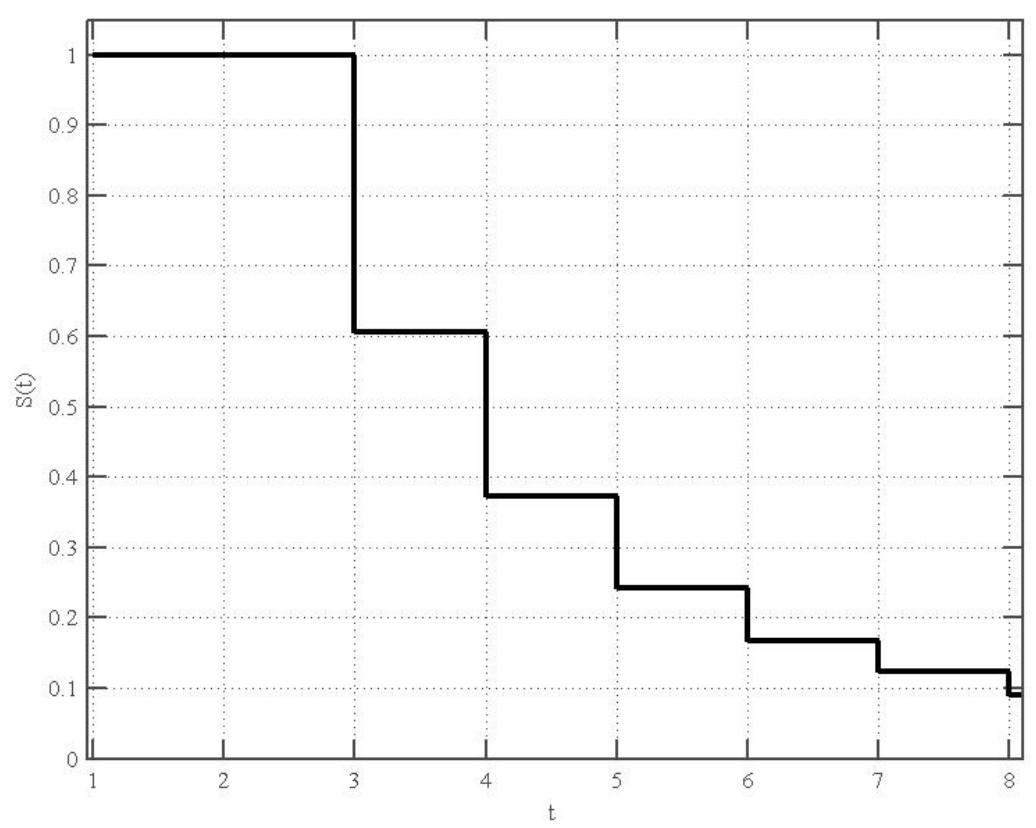

Figure 2: Survivor function

The survivor function plotted in this figure, $S(t)=P\{T>t\}$, represents the survivorship of bank $_{i}$ whose covariate values are equal to the average. The average estimation of this survival function indicates that after 8 years of arranging project finance loans, $92.5 \%$ of the banks in our sample adopt the Equator Principles (survival rate= $7.5 \%$ ) 


\section{Table 1: Loan characteristics of banks that adopt and do not adopt the Equator Principles}

This table presents the lending characteristics of the banks in our sample that have not adopted the Equator Principles (Panel A) and the lending characteristics of the banks in our sample that have adopted the Equator Principles (Panel B). Loan amounts are presented in million U.S. dollars and they correspond to the share of the loan arranged by banks calculated as the ratio between loan size and the number of arrangers in a given year. Observation period: 2003-2010

\begin{tabular}{|c|c|c|c|c|c|c|c|}
\hline & Mean & Min & $25 \%$ ile & Median & $75 \%$ ile & Max & Std.Dev. \\
\hline \multicolumn{8}{|c|}{ Panel A: Sub-sample of banks that have not adopted the Equator Principles } \\
\hline Loan Amount (USD MM) & $1,662.21$ & 0.00 & 46.95 & 159.27 & 749.03 & $190,858.13$ & $7,559.19$ \\
\hline Project Finance Amount (USD MM) & 14.71 & 0.00 & 0.00 & 0.00 & 0.00 & $4,206.42$ & 121.89 \\
\hline Number of Project Finance Loans & 0.11 & 0.00 & 0.00 & 0.00 & 0.00 & 8.00 & 0.50 \\
\hline Number of Loans & 15.46 & 1.00 & 1.00 & 2.00 & 10.00 & 1007.00 & 47.79 \\
\hline Project Finance Concentration & 0.02 & 0.00 & 0.00 & 0.00 & 0.00 & 1.00 & 0.01 \\
\hline Number of Lender Collaborations & 141.14 & 1.00 & 6.00 & 19.00 & 89.00 & $9,712.00$ & 487.46 \\
\hline Number of Arranger Collaborations & 72.43 & 1.00 & 3.00 & 12.00 & 49.00 & 3,203 & 211.47 \\
\hline \multicolumn{8}{|l|}{$\mathrm{N}_{\text {bank-year }}=60,327$} \\
\hline \multicolumn{8}{|c|}{ Panel B: Sub-sample of banks that have adopted the Equator Principles } \\
\hline Loan Amount (USD MM) & $15,994.58$ & 2.85 & 216.16 & $2,341.99$ & $15,406.93$ & $503,362.95$ & $39,147.57$ \\
\hline Project Finance Amount (USD MM) & 93.45 & 0.00 & 0.00 & 0.00 & 34.93 & 4264.01 & 309.47 \\
\hline Number of Project Finance Loans & 0.85 & 0.00 & 0.00 & 0.00 & 1.00 & 15.00 & 1.99 \\
\hline Number of Loans & 123.77 & 1.00 & 2.00 & 23.00 & 152.00 & 913.00 & 191.86 \\
\hline Project Finance Concentration & 0.01 & 0.00 & 0.00 & 0.00 & 0.00 & 0.54 & 0.04 \\
\hline Number of Lender Collaborations & $1,095.25$ & 1.00 & 2.00 & 23.00 & $1,586.00$ & $9,382.00$ & $1,698.75$ \\
\hline Number of Arranger Collaborations & 572.30 & 1.00 & 12.00 & 107.00 & 787.00 & $4,320.00$ & 867.23 \\
\hline Number of adopters in North America & 8 & & & & & & \\
\hline Number of adopters in South America & 4 & & & & & & \\
\hline Number of adopters in Europe & 26 & & & & & & \\
\hline Number of adopters in Africa/Middle East & 5 & & & & & & \\
\hline Number of adopters in Asia and Oceania & 7 & & & & & & \\
\hline $\mathrm{N}_{\text {bank-year }}=41,835$ & & & & & & & \\
\hline
\end{tabular}

\section{Table 2: Descriptive statistics}

Summary statistics for the set of explanatory variables for a total of 41,403 bank $_{i j}$ pair-year

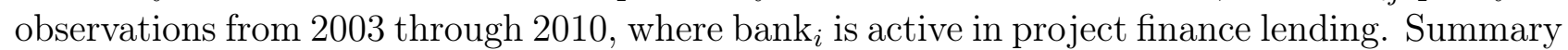
statistics are calculated at the bank $_{i}$ level. Banks $i$ that do not collaborate in arranging loans are excluded from this sample.

\begin{tabular}{lrrrrrrrr}
\hline Covariate & $\mathrm{N}$ & Mean & Min & $25 \%$ ile & Median & $75 \%$ ile & Max & Std.Dev. \\
\hline Peer Pressure $i j$ & 41,403 & 0.01 & 0.00 & 0.00 & 0.00 & 0.00 & 1.00 & 0.03 \\
& & & & & & & & \\
Controls: & & & & & & & & \\
Number Project Finance Loans $_{i}$ & 41,403 & 12.98 & 0.00 & 0.00 & 4.00 & 15.00 & 124.00 & 20.62 \\
Equator Bank $_{j}$ & 41,403 & 0.23 & 0.00 & 0.00 & 0.00 & 0.00 & 1.00 & 0.42 \\
Number Equator Relationships $_{i}$ & 41,403 & 19.59 & 0.00 & 11.00 & 18.00 & 28.00 & 49.00 & 11.37 \\
Concentration $_{i j}$ & 41,403 & 0.05 & 0.00 & 0.01 & 0.02 & 0.06 & 1.00 & 0.11 \\
Public Pressure $_{i}^{t-1}$ & 38,316 & 0.21 & 0.00 & 0.00 & 0.00 & 0.00 & 1.00 & 0.41 \\
Country ESG $_{i}$ & 36,006 & 53.72 & 33.41 & 50.17 & 54.46 & 58.8 & 63.58 & 6.27 \\
\hline \hline
\end{tabular}




\section{Table 3: Estimations}

This table presents the hazard estimates from our Cox Proportional Hazards regression. Clustered standard errors by bank pair and reported in brackets. Unbalanced panel. Generalized R-sq calculated as follows: $R^{2}=1-\exp \left(-G^{2} / n\right)$, where $\mathrm{G}^{2}$ is the likelihood ratio chi-square statistic for testing the null hypothesis that all covariates have coefficient estimates equal to 0 , and $\mathrm{n}$ is the number of observations.

\begin{tabular}{|c|c|c|c|c|}
\hline Covariate & $(1)$ & $(2)$ & $(3)$ & $(4)$ \\
\hline Peer Pressure $_{i j}$ & $\begin{array}{c}2.629^{* * *} \\
{[0.2474]}\end{array}$ & $\begin{array}{c}2.673^{* * *} \\
{[0.2548]}\end{array}$ & $\begin{array}{c}2.503^{* * *} \\
{[0.2708]}\end{array}$ & $\begin{array}{c}2.575^{* * *} \\
{[0.2748]}\end{array}$ \\
\hline \multicolumn{5}{|l|}{ Controls: } \\
\hline Number Project Finance Loans $_{i}$ & $\begin{array}{c}1.002^{* * *} \\
{[0.0003]}\end{array}$ & $\begin{array}{l}1.000 \\
{[0.0003]}\end{array}$ & $\begin{array}{c}1.002^{* * *} \\
{[0.0004]}\end{array}$ & $\begin{array}{l}1.000 \\
{[0.0004]}\end{array}$ \\
\hline Equator $\mathrm{Bank}_{j}$ & $\begin{array}{c}0.929^{* * *} \\
{[0.0259]}\end{array}$ & $\begin{array}{c}0.936^{* * *} \\
{[0.0251]}\end{array}$ & $\begin{array}{c}0.947^{*} \\
{[0.0293]}\end{array}$ & $\begin{array}{c}0.951^{*} \\
{[0.0286]}\end{array}$ \\
\hline Number Equator Relationships $_{i}$ & $\begin{array}{c}1.075^{* * *} \\
{[0.0014]}\end{array}$ & $\begin{array}{c}1.068^{* * *} \\
{[0.0014]}\end{array}$ & $\begin{array}{c}1.071^{* * *} \\
{[0.0018]}\end{array}$ & $\begin{array}{l}1.068^{* * *} \\
{[0.0018]}\end{array}$ \\
\hline Concentration $_{i j}$ & $\begin{array}{c}1.541^{* * *} \\
{[0.0527]}\end{array}$ & $\begin{array}{c}1.510^{* * *} \\
{[0.0533]}\end{array}$ & $\begin{array}{l}1.596^{* * *} \\
{[0.0575]}\end{array}$ & $\begin{array}{c}1.591^{* * *} \\
{[0.0571]}\end{array}$ \\
\hline Public Pressure $_{i}^{t-1}$ & & $\begin{array}{c}1.606^{* * *} \\
{[0.0136]}\end{array}$ & & $\begin{array}{c}1.341^{\text {*** }} \\
{[0.0147]}\end{array}$ \\
\hline Country $\mathrm{ESG}_{i}$ & & & $\begin{array}{c}0.993^{* * *} \\
{[0.0023]}\end{array}$ & $\begin{array}{c}0.994^{* * *} \\
{[0.0022]}\end{array}$ \\
\hline Generalized R-sq & 0.1470 & 0.1688 & 0.1205 & 0.1342 \\
\hline $\mathrm{N}$ & 41,403 & 38,316 & 36,006 & 33,307 \\
\hline
\end{tabular}

Standard errors in brackets

${ }^{*}(\mathrm{p}<0.10),{ }^{* *}(\mathrm{p}<0.05),{ }^{* * *}(\mathrm{p}<0.01)$ 


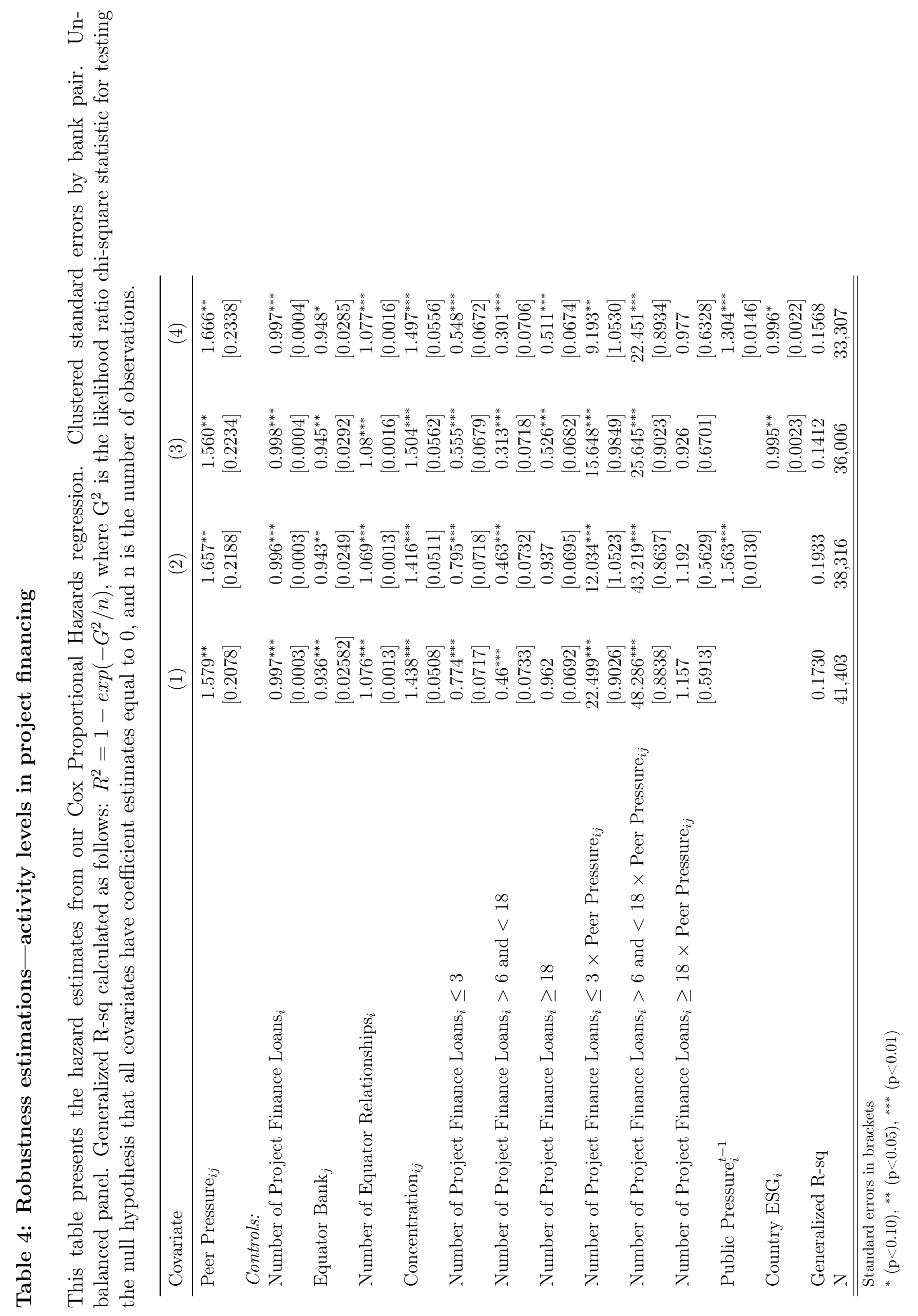


Table 5: Robustness estimations - countries with high adoption rates

This table presents the hazard estimates from our Cox Proportional Hazards regression. Clustered standard errors by bank pair. Unbalanced panel. Generalized R-sq calculated as follows: $R^{2}=1-\exp \left(-G^{2} / n\right)$, where $\mathrm{G}^{2}$ is the likelihood ratio chi-square statistic for testing the null hypothesis that all covariates have coefficient estimates equal to 0 , and $\mathrm{n}$ is the number of observations.

\begin{tabular}{|c|c|c|c|c|}
\hline Covariate & (1) & $(2)$ & $(3)$ & $(4)$ \\
\hline Peer Pressure $_{i j}$ & $\begin{array}{c}1.682^{* * *} \\
{[0.2153]}\end{array}$ & $\begin{array}{c}1.820^{* * *} \\
{[0.2215]}\end{array}$ & $\begin{array}{c}1.679^{* * *} \\
{[0.2149]}\end{array}$ & $\begin{array}{c}1.819^{* * *} \\
{[0.2215]}\end{array}$ \\
\hline Controls: & & & & \\
\hline Number of Project Finance Loans $i$ & $\begin{array}{c}0.996^{* * *} \\
{[0.0002]}\end{array}$ & $\begin{array}{c}0.994^{* * *} \\
{[0.0002]}\end{array}$ & $\begin{array}{c}0.996^{* * *} \\
{[0.0002]}\end{array}$ & $\begin{array}{c}0.994^{* * *} \\
{[0.0002]}\end{array}$ \\
\hline Equator Bank $_{j}$ & $\begin{array}{c}0.893^{* * *} \\
{[0.0287]}\end{array}$ & $\begin{array}{c}0.893^{* * *} \\
{[0.0275]}\end{array}$ & $\begin{array}{c}0.894^{* * *} \\
{[0.0288]}\end{array}$ & $\begin{array}{c}0.893^{* * *} \\
{[0.0275]}\end{array}$ \\
\hline Number of Equator Relationships ${ }_{i}$ & $\begin{array}{l}1.071^{* * *} \\
{[0.0016]}\end{array}$ & $\begin{array}{c}1.068^{* * *} \\
{[0.0016]}\end{array}$ & $\begin{array}{l}1.072^{* * *} \\
{[0.0016]}\end{array}$ & $\begin{array}{c}1.068^{* * *} \\
{[0.0016]}\end{array}$ \\
\hline Concentration $_{i j}$ & $\begin{array}{l}1.250^{* * *} \\
{[0.0497]}\end{array}$ & $\begin{array}{c}1.221^{* * *} \\
{[0.0487]}\end{array}$ & $\begin{array}{l}1.255^{* * *} \\
{[0.0499]}\end{array}$ & $\begin{array}{c}1.222^{* * *} \\
{[0.0488]}\end{array}$ \\
\hline Public Pressure $_{i}^{t-1}$ & & $\begin{array}{l}1.457^{* * *} \\
{[0.0145]}\end{array}$ & & $\begin{array}{c}1.456^{* * *} \\
{[0.0142]}\end{array}$ \\
\hline Country $\mathrm{ESG}_{i}$ & & & $\begin{array}{c}0.992^{* *} \\
{[0.0036]}\end{array}$ & $\begin{array}{c}0.999 \\
{[0.0029]}\end{array}$ \\
\hline Generalized R-sq & 0.1217 & 0.1455 & 0.1220 & 0.1455 \\
\hline $\mathrm{N}$ & 17,648 & 16,170 & 17,648 & 16,170 \\
\hline
\end{tabular}

Standard errors in brackets

${ }^{*}(\mathrm{p}<0.10),{ }^{* *}(\mathrm{p}<0.05),{ }^{* * *}(\mathrm{p}<0.01)$ 


\section{Table 6: Robustness estimations - extreme peer pressure}

This table presents the hazard estimates from our Cox Proportional Hazards regression. Clustered standard errors by bank pair. Unbalanced panel. Generalized R-sq calculated as follows: $R^{2}=1-\exp \left(-G^{2} / n\right)$, where $\mathrm{G}^{2}$ is the likelihood ratio chi-square statistic for testing the null hypothesis that all covariates have coefficient estimates equal to 0 , and $\mathrm{n}$ is the number of observations.

\begin{tabular}{lcccc}
\hline Covariate & $(1)$ & $(2)$ & $(3)$ & $(4)$ \\
\hline Peer Pressure $_{i j}$ & $4.709^{* * *}$ & $5.066^{* * *}$ & $4.988^{* * *}$ & $5.418^{* * *}$ \\
& {$[0.4876]$} & {$[0.4818]$} & {$[0.4939]$} & {$[0.4885]$} \\
Controls: & & & & \\
Number of Project Finance Loans & & & \\
& 0.994 & 0.993 & 0.998 & 0.998 \\
Equator Bank $_{j}$ & {$[0.0041]$} & {$[0.0042]$} & {$[0.0047]$} & {$[0.0048]$} \\
& $0.699^{* *}$ & 0.723 & 0.694 & 0.722 \\
Number of Equator Relationships $_{i}$ & {$[0.2164]$} & {$[0.2187]$} & {$[0.2370]$} & {$[0.2322]$} \\
& $1.052^{* * *}$ & $1.048^{* * *}$ & $1.026^{*}$ & $1.025^{*}$ \\
Concentration $_{i j}$ & {$[0.0127]$} & {$[0.0126]$} & {$[0.0145]$} & {$[0.0143]$} \\
& $1.782^{* *}$ & $1.704^{* *}$ & $1.627^{*}$ & $1.58^{*}$ \\
Public Pressure $_{i}^{t-1}$ & {$[0.2757]$} & {$[0.2540]$} & {$[0.3001]$} & {$[0.2721]$} \\
& & $1.499^{* *}$ & & 1.271 \\
Country ESG $_{i}$ & & {$[0.1767]$} & & {$[0.2152]$} \\
& & & $1.057^{* * *}$ & $1.057^{* * *}$ \\
Generalized R-sq & & & {$[0.0234]$} & {$[0.0231]$} \\
N & 0.1690 & 0.1856 & 0.1576 & 0.1726 \\
\hline \hline
\end{tabular}

Standard errors in brackets

* $(\mathrm{p}<0.10),{ }^{* *}(\mathrm{p}<0.05),{ }^{* * *}(\mathrm{p}<0.01)$ 